\title{
Basement control, sedimentary basin inception and early evolution of the Mesozoic basins in the Patagonian foreland
}

\author{
Raúl E. Giacosa ${ }^{\mathrm{a}, \mathrm{b}, *}$ \\ ${ }^{a}$ Servicio Geológico Minero Argentino, Instituto Geología Recursos Minerales, General Roca, Río Negro, Argentina \\ ${ }^{\mathrm{b}}$ Instituto de Paleobiología y Geología, Universidad Nacional de Río Negro-CONICET, General Roca, Río Negro, Argentina
}

\section{A R T I C L E I N F O}

\section{Keywords:}

Patagonian foreland

Mesozoic

Rift basin

Basement structures

\begin{abstract}
A B S T R A C T
The Golfo San Jorge basin and other Mesozoic basins occupy extensive areas of the extra-Andean Argentinean Patagonia. These basins initiated and evolved from the Jurassic as rift basins on an igneous-metamorphic and sedimentary Paleozoic basement. Several studies have indicated that basement structures might have influenced their configuration in their initial stages.

Based on an updated synthesis of the structures and fabrics of the Paleozoic basement in the Patagonian foreland, and its comparison with fundamental structures of the Mesozoic basins, this work investigates the existence of relations among them, identifying common control types to most of these basins.

The comparison suggests that W-E to WNW-ESE structures controlled those basin sectors located near the Atlantic margin, with scarce evidence of basement control. In the Golfo San Jorge basin, basement control can be observed in the thinnest sedimentary sectors on basements, as part of the Río Chico paleo-high.

In general, it is possible to establish closer relations with the basement structures towards the continent interior, in the areas with structural reliefs that are currently striking NNW, NW, and WNW. Here, the main structures layout in some of these depocenters could be compared with the direction and vergence of the Paleozoic foliations and shear zones.

The lower Paleozoic structures of the Deseado orogen influenced those sectors further from the Atlantic margin of the Deseado basin and, possibly, the San Bernardo fold belt. Northward of the Golfo San Jorge basin, curved orogenic fabrics linked to the Gondwanic structures determine variations in the orientation of the main depocentres of the Cañadón Asfalto basin. Its influence reaches the northern boundary of Patagonia in the Neuquén basin depocenters, located in the Huincul ridge.
\end{abstract}

\section{Introduction}

The interaction among the mantle convection, the lithosphere rheology, and the structural weaknesses of the late Paleozoic basement controlled the Pangea evolution and its final breakup, which includes the development of numerous extensional Mesozoic basins located in the southwestern Gondwana margin (Franzese et al., 2003). These weakness zones constituted the location of both intracontinental extensional and transtensional deformation belts with an NNW, NW and WNW orientation, which characterize the initiation and development of the Triassic and Jurassic rifts (Vizán et al., 2017; Renda et al., 2019).

The Mesozoic basins occupy extensive areas of the extra-Andean Argentinean Patagonia (Fig. 1A) and share some of the main tectonostratigraphic characteristics. Among them, their inception during the Jurassic, in an extensional tectonic regime with abundant volcanism and subordinated sedimentation; and later, during the Cretaceous, with significant sedimentation, mainly continental, whose tectonic control has been associated to either a thermal subsidence regime (Figari et al., 1999, 2015; Ranalli et al., 2011; Sylwan et al., 2011) or sedimentation controlled by normal faults induced by the Andean compression of the Late Cretaceous (Ramos, 2015), named as synorogenic foreland rift stage (Gianni et al., 2015; Folguera et al., this issue). In both regimes, there are evidences of a phase of positive tectonic inversion during the middle of the Cretaceous (Allard et al., 2011; Ranalli et al., 2011; Ramos, 2015; Gianni et al., 2015; Echaurren et al., 2016, 2017, among others), as well as previous inversion events occurring between the Liassic and the Dogger (Allard, this issue; Navarrete et al., 2018, 2019).

Models of continental rifting commonly assume the upper crust is homogeneous, with extensional faults striking broadly perpendicular to the regional extension direction (e.g. Gupta et al., 1998; Gawthorpe and

\footnotetext{
* Servicio Geológico Minero Argentino, Instituto Geología Recursos Minerales, Barrio Industrial, (8332) General Roca, Río Negro, Argentina.

E-mail address: rgiacosa@unrn.edu.ar.
} 


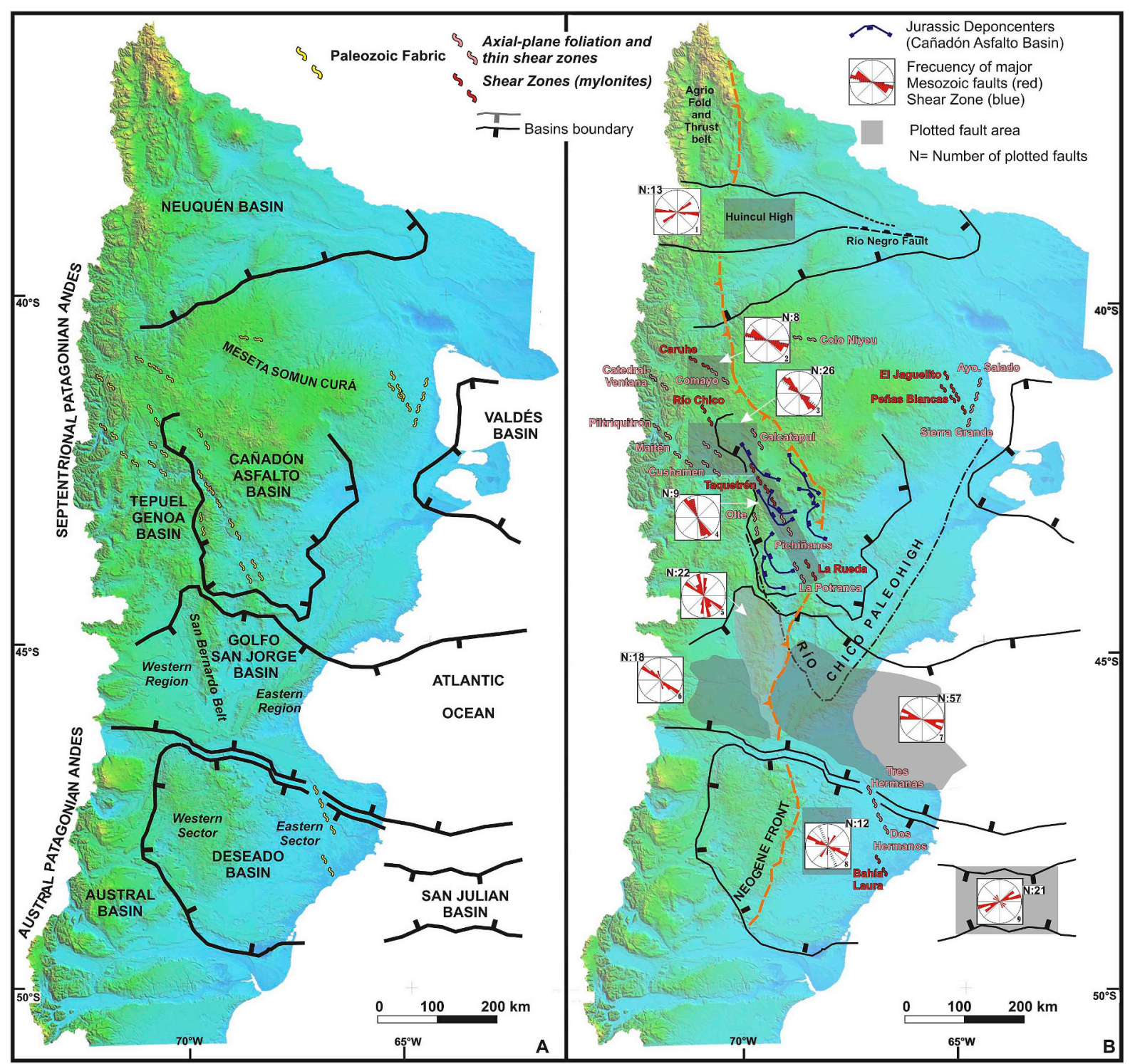

Fig. 1. A. Main Mesozoic basins in the Extrandean Argentinean Patagonia. Major divisions of the Golfo San Jorge and Deseado basins are indicated. The Paleozoic basin of Tepuel-Genoa and the Patagonian Andes have been located as a reference. The general orientation of the tectonic fabric associated with Paleozoic igneousmetamorphic rocks is indicated (yellow). Observe how, from south to north, the fabric design gradually changes from NNW, NW, WNW, to W-E in the extreme north of Patagonia. B. Paleozoic tectonic fabrics discriminated in shear zones (red) and thin shear zones interlayered with axial-plane and crenulation foliation zones (pink). Location of the main Jurassic depocenters-bounding faults (blue) of the Cañadón Asfalto basin (from Figari et al., 2015). Frequency diagrams (rosnet) of faults greater than $10 \mathrm{~km}$ long located within the shaded areas, with data from (1) Silvestro and Zubiri (2008); (2) Giacosa and Heredia (2004); (3, 4) Giacosa et al. (2017); (5, 6, 7) Figari et al. (1999); (8) Giacosa et al. (2010); (9) Figueiredo et al. (1996). The orange line indicates the eastern limit of the Neogene deformation front in the Patagonian foreland. (For interpretation of the references to colour in this figure legend, the reader is referred to the Web version of this article.)

Leeder, 2000). However, several field-, seismic reflection-, and modelling-based studies indicate that pre-existing heterogeneities localized within pre-rift sedimentary or crystalline rocks underlying nascent rifts can influence the distribution, scale, and kinematics of rift-related normal fault arrays (e.g. Faccenna et al., 1995; Henza et al., 2011). Basement heterogeneities can thus shape the overall rift physiography, driving development of normal faults striking oblique to the regional principal stress axes. These potential impacts on fault arrays imply that fault strikes cannot easily be used to infer extension direction in areas where basement heterogeneities are present (e.g., Morley et al., 2004; Reeve et al., 2014).

Numerous studies of these basins and, particularly, of those with an oil-bearing interest, indicate the existence of control in their inception and later evolution by previous structures, referred to as anisotropies, fabrics, lineaments, heterogeneities or previous/basement cortical weaknesses.
The geometry and distribution of underlying basement heterogeneities dictate the location of many basin margins, determining the initial rift physiography and its size (Phillips et al., 2016). Besides, the repeated reactivation of these structures shows how they play a permanent role in the evolution of the rift system throughout multiple tectonic events. Basement heterogeneities in the pre-Mesozoic basement might have controlled the normal faulting in basin boundaries and transfer zones within depocenters, the design and geometry of basin-bounding faults, and the resulting structural styles, particularly those associated with tectonic inversion events (Daly et al., 1989; Maurin and Guiraud, 1993; Ring, 1994; Withjack et al., 2002; Morley et al., 2004).

The control of basement structures over basin successions is limited at the beginning of the extension event but dominant in the development of syn-rift sequences, being more straightforward than during thermal sag stages when these relations are usually masked (Withjack 
et al., 2002; Kristensen et al., 2016). Basement control over the inception and development of rift basins of Mesozoic age implies a tectonic inversion regime (Coward, 1994; Buchanan and Buchanan, 1995), and the extensional re-shearing of previous Paleozoic structures and fabrics.

Several basin evolution studies analyze the development of intracontinental extensional basins and passive margin basins from the reactivation of pre-rift basement structures. In general, it is indicated that rift faults mainly use ductile and ductile-brittle shear zones constituted by either wide mylonitic belts or narrow belts separated by undeformed rocks (Daly et al., 1989; Maurin and Guiraud, 1993; Ring, 1994; Clemson et al., 1997; Morley et al., 2004; Paton and Underhill, 2004; Gontijo-Pascutti et al., 2010; Whipp et al., 2014, Salomon et al., 2015; Phillips et al., 2016, among others).

In Argentina, relations between Paleozoic mylonitic belts and basins have been studied in the Cretaceous basins of the Sierras Pampeanas of Córdoba (Martino et al., 2012; Oviedo and Astini, 2014) and the Triassic Cuyo basin (Ramos and Kay, 1990). In regions of Patagonia, such as the Neuquén basin, previous works highlight the influence of the North Patagonian basement in the initiation and evolution of the Huincul ridge depocenters (Mosquera and Ramos, 2006). In a framework of few studies of basin-basement relations, two points are remarkable in the Golfo San Jorge basin. On a regional scale, inherited tectonic structures controlled the location of the San Bernardo Fold Belt (Allard et al., this issue), and at a reservoir scale, the basement fault geometry and orientation influenced the architecture of overlying extensional faults (Giampaoli, 2015; Paredes et al., 2013, 2018; Guerra et al., 2019).

Pioneer studies in the east African rifts identified two modes of extensional reactivation of ductile high-strain zones (Daly et al., 1989): (1) dip-slip extensional reactivation of gently-dipping fabrics and structures (e.g., thrust shear zones), and (2) strike-slip reactivation of steeply-dipping fabrics and structures (e.g., strike-slip shear zones) acting as major strike-slip transfers zones. As a rule, the pre-existing anisotropy will be difficult to reactivate by displacements perpendicular to steeply-inclined structures, but easy to reactivate through displacements either parallel or subparallel to them.

The analysis of high-resolution seismic reflection data in the basement indicates three main modes of extensional re-shearing of postorogenic extensional shear zones (Phillips et al., 2016): a) the exploitative fault model, in which normal faults utilize shear belts with mylonites located inside the basement, and b) the merging fault model, with normal faults that initiate in the hanging-wall of shear zones with a similar orientation, connecting at depth. Finally, a third model referred to as the cross-cutting fault model, includes those faults with no geometrical or kinematical control of the underlying basement. These three models can be present in a single basin, and interact with each other. Thus, master normal faults on the edge of a half-graben can cut basement structures in order to develop listric fault geometries at depth, being localized at depth within a mylonite zone.

Besides the geometric relations pointed out, it is important to highlight another derivation inherent to the stress field. Rift fault orientation is a response to the regional stress field but basement heterogeneities can act as zones of weaknesses that may reactivate during later tectonic promote nucleation of later faults, and/or locally modify the regional stress field (Faccenna et al., 1995; Morley et al., 2004; Phillips et al., 2016; Morley, 2017).

In order to establish relations between the Patagonian Mesozoic basins and their basement, it is essential to identify previous orogenic structures and investigate at least two aspects. On the one hand, which would be "the structures of the Patagonian basement" with the ability to control the limits of future basins or transfer zones? On the other hand, how to establish whether the main basin structures are related to the orientation of an orogenic structure or fabric?

This evaluation poses two drawbacks. First, basement outcrops are of small scale, isolated and except rocks in the eastern sector of the
North Patagonian Massif (Greco et al., 2015; González et al., 2018), they lack detailed structural studies. Some preliminary studies include rocks in the Bariloche and Pilcaniyeu region (Giacosa and Heredia, 2004; García-Sansegundo et al., 2008), Gastre region (Von Gosen, 2009; Giacosa et al., 2017), Taquetren and Pichiñanes ranges (Allard, 2015; Renda et al., 2019) and La Rueda (Giacosa et al., 2008). Second, the available 3D seismic sections lack the appropriate resolution at basement levels. Likewise, cutting record calibrations of formation tops recovered during drilling operations, allow to adjust the limits of the seismic sequences and to constrain the lithological interpretations. Even in seismic sections where pre-rift faults are identified, it is still difficult to discern the type of reactivated fabric. Therefore, inferring the basement-basin relations is mainly limited to comparing rift geometries with the observed geometry in outcrops of either discrete ductile or ductile-brittle shear zones or metamorphic zones with folding, foliation and intercalated mylonite belts.

On a continental scale, the reactivation of Paleozoic cortical weaknesses of NNW, NW and WNW orientation controlled the sedimentary basin development in the Patagonian crust during the Triassic and the Jurassic. Later on ( $c a .150 \mathrm{Ma}$ ), and linked to the Atlantic Ocean opening, the basins located in the eastern edge of the continent and progressively towards the continental interior were controlled by W-E faults (Japas et al., 2017).

Taking this premise into account, what follows is a description of evidence supporting the hypothesis of control of the orogenic structures of the lower Paleozoic and Neopaleozoic basements of Patagonia and the inception and development of Mesozoic basins.

\section{Structural context}

\subsection{Structural lineaments in Patagonia}

N-S Andean lineaments, together with other W-E to WNW-ESE transversal lineaments, and NW-SE to NNW-SSE oblique orientations, constitute the dominant structural orientations in Patagonia, which are reproduced in several regional features of first-order such as limits among provinces or geological regions, structural relief and Mesozoic basin boundaries, and in other scale, in the location and geometry of depocenters and structural styles. Depending on the analyzed sector, these orientations either coincide with the Paleozoic orogenic structures or they crosscut these structures.

\subsection{Paleozoic structural domains}

The Paleozoic orogenic fabrics southward of the Golfo San Jorge basin outcrop in few places in the eastern sector of the Deseado region, as part of a set of igneous-metamorphic rocks assigned to the Río Deseado Complex (Fig. 1B) (Viera and Pezzuchi, 1976). It is a basement with structures of several ductile deformation phases, including three folding phases and the dextral-reverse ductile "Bahía Laura shear zone" developed during the lower Paleozoic, before the 393 Ma granitoids (Giacosa et al., 2006). All these structures, along with a post-metamorphic thin-skinned fold-and-thrust belt located on the Las Tres Hermanas, have a consistent NNW orientation, which indicates a persistent regional shortening for the whole the region, of WSW-ENE to WE orientation and W to WSW vergence (Fracchia and Giacosa, 2006).

To the west, in the western border of the Deseado region, there is low-grade metamorphic rock assigned to the La Modesta Formation (Di Persia, 1962), whose Devonian protoliths proceed from the exhumation of the Río Deseado Complex rocks (Permuy Vidal et al., 2014). In the area, there is no mention of shear zones, and the $S_{1}$ y $S_{2}$ fabrics associated with metamorphism appear reoriented by NW-SE strike folds (Moreira et al., 2012).

The post-orogenic upper Paleozoic deposits in the Deseado region are part of the La Golondrina basin, a Permian intracontinental rift controlled by NNW to N-S normal faults, "the Permian-Triassic 
extensional trend" (Homovc et al., 1996), possibly developed from the negative inversion of the Río Deseado Complex orogenic fabric. In the eastern region, this control of basement structures appears to continue until the Liassic, during the filling controlled by thermal subsidence (Cortiñas et al., 2005). Eastward of $68^{\circ} 30^{\prime} \mathrm{W}$ longitude and in the Atlantic margin of the Deseado region, the Jurassic volcanic rift regime is uncoupled from basement structures, being controlled by WNW-ESE transversal faults (Homovc and Constantini, 2001). In the nearby San Julián basin (Fig. 1B), the main faults strike WSW-ENE, but some depocenters, such as the "NW-graben" of Figueiredo et al. (1996) has an NW-SE orientation, suggesting a basement control in this part of the basin. This new structural organization appears to be immediately posterior to a positive tectonic inversion phase, evidenced further north in the Golfo San Jorge basin, in the unconformity that separates the Liassic sedimentary deposits from the overlying volcanic deposits of the Lonco Trapial Formation at the Ferrarotti farm (Allard et al., this issue) and in the Río Mayo sub-basin (Navarrete et al., 2018).

To the west and northwest of the Golfo San Jorge Basin, the Carboniferous and Permian deposits of the Tepuel-Genoa basin might have accumulated in extensional to transtensional depocenters of NNWSSE orientation (Ugarte, 1966). In their type section, sediments have NNE folds and an NW vergence with axial plane foliation and incipient pencil lineation, associated with a very low metamorphic grade developed during the late Permian, previous to the Liassic marine ingression (Márquez and Giacosa, 2000). It is worth mentioning that the analysis of both outcrop and subsurface data in the Ferrarotti farm area (Allard et al., this issue) indicate that an intra-Cretaceous contraction phase deformed the Neopaleozoic-Liassic sedimentary succession. The structure of the basement shows a folded angular unconformity between the Upper Paleozoic Tepuel Group and the Liassic succession, and the occurrence of N-S- folds of different scale (Allard et al., this issue).

Towards the north of the Golfo San Jorge basin, pre-Mesozoic structures are mainly related to the Gondwanic basement, characterized by ductile structures and fabrics in various deformation phases associated with continuous igneous activity. Von Gosen (2009) ordered this tectonic and magmatic activity by proposing four phases $\left(D_{1}\right.$ to $\left.D_{4}\right)$, of which the second one $\left(D_{2}\right)$, which occurred in the Permian, is the most regionally penetrative. On a regional scale (Fig. $1 B)$, the $\left(D_{2}\right)$ orientation is changing evidencing the curved character of the orogenic belt: NW to NNW striking in the Taquetrén, Pichiñanes, Río Chico and Calcatapul ranges, rotating to WNW-NW striking in Cushamen, Comallo, Pilcaniyeu and the Catedral hill, to W-E striking in the northern limit of the North Patagonian Massif, near the Huincul ridge area and the vicinity of the Río Negro fault (Von Gosen, 2009; Mizerit et al., 2014; Giacosa et al., 2017). As will be described, these path changes can be compared to the variations in the basin-bounding fault orientations of various Jurassic depocenters in the Cañadón Asfalto basin.

Near the Chubut river between $43^{\circ}$ and $44^{\circ} \mathrm{S}$ latitude, there are several outcrop exposures of the Gondwanic basement. Among them, the La Rueda granitic mylonites belt (Fig. 1B) has a N-S to NNW fabric, and has been folded together with Jurassic volcanic rocks (Giacosa et al., 2008), whereas the La Potranca metamorphic rocks show a strong NNW foliated fabric (Anselmi et al., 2000). In the core of the Pichiñanes range there are exposures of the high-grade metamorphic rocks and Carboniferous granitoids with an NW fabric (Allard, 2015). Of particular interest to this contribution is the Paleozoic granitic mylonites belt on the western face of the Taquetrén range (Renda et al., 2019), whose NW-strike fabric has been re-sheared several times. The outcrops of Sierra Mora, La Rueda and La Potranca and the subsurface basement at depth of 1000 and 2000 ma.s.l., are part of the Río Chico paleohigh (Fig. 1B), whose western edge constitute the eastern boundary of the San Bernardo fold belt (Allard et al., this issue: their Fig. 18).

Between $42^{\circ}$ and $43^{\circ} \mathrm{S}$ latitude, the Gondwanic basement in Cushamen presents a penetrative ductile fabric of NW orientation that includes various intercalated shear zones of SW vergence (Giacosa et al., 2004). In the Río Chico locality, the Andean deformation front is an inheritance from the NNW Gondwanic faults of NE vergence (GarcíaSansegundo et al., 2008). At $41^{\circ} \mathrm{S}$ and toward the Negro river, the Gondwanic fabrics have a WNW-ESE and W-E orientation, as is the case of the Loma Caruhé mylonites (Giacosa and Heredia, 2004), the Catedral hill metamorphic rocks (Giacosa and Heredia, 2004) and the bajo of Lenzaniyeu to the west of Los Menucos (Cucchi et al., 2001). The W-E orientations are characteristic of the basement faults in the Huincul ridge (Fig. 1B) (Mosquera and Ramos, 2006; Silvestro and Zubiri, 2008), as well as in their eastern continuation in the Río Negro fault (Roberts, 2018). Between the Río Negro fault and the Los Menucos locality, in an area of more than $200 \mathrm{~km}$ wide, the W-E Colo Niyeubasement fabric (Fig. 1B) shows several extensional and transtensional reactivations, at least in the late Permian-Triassic, Upper Triassic and in the Lower Jurassic (Mizerit et al., 2014).

In the eastern sector of the Nordpatagonian Massif, far from the Mesozoic depocenters, there are two types of ductile Paleozoic structures (Fig. 1B). On the one hand, the structures and metamorphic fabrics of the Lower Paleozoic Arroyo Salado fold and thrust belt, and the El Jaguelito and Peñas Blancas Gondwanic ductile-brittle shear zones (Giacosa, 2001; González et al., 2018). Regarding the real influence of the lower Paleozoic basement structures in the North Patagonian Massif, it is worth to mention that significant exposures of these rocks are currently re-oriented towards ENE-ESE due to the Gondwanic orogeny, modifying their original orientation, as in the Aguada CecilioValcheta region (Greco et al., 2015).

\subsection{Structures in Mesozoic basins}

Mesozoic basins in the extra-Andean Patagonia present structures distributed in two or more preferred orientations, which prevailed in specific basin sectors. Their distribution in groups allows identifying structural domains with a consistent orientation in a certain area, being possible to compare them with basement structures. In the Golfo San Jorge Basin, this situation is noticeable, and it has determined the classic tectonic division into five different regions according to their present structural style.

Deseado basin. This basin occupies much of the Deseado region and is better known in the eastern sector located between the $69^{\circ} \mathrm{W}$ and the Atlantic margin. It includes two tectostratigraphic cycles (Cortiñas et al., 2005) also recognizable in the nearby shelf in the San Julián basin (Figueiredo et al., 1996). The first cycle begins in the Permian with an intracontinental rifting controlled by N-S normal faults starting from the extensional reactivation of the Lower Paleozoic basement structures of the Deseado region (Homovc and Constantini, 2001), and it finishes in the Liassic in thermal subsidence conditions. The second cycle is a new rifting that begins in the Jurassic, with volcaniclastic grabens and half-grabens limited by large WNW-ESE normal faults in an oblique normal-dextral extensional regime (Giacosa et al., 2010). In the eastern sector, this second cycle does not have a significant basement control in these first-order faults, except for sub-basins such as the "NWgraben" in the San Julián basin (Figueiredo et al., 1996). Although there is no subsurface information, towards the west of the $69^{\circ} \mathrm{W}$, basins and structural relief are limited by NNE to NNW faults, orientations that are similar to the Gondwanic magmatic arc (Pankhurst et al., 2006; Ramos, 2008), the trend of the Deseado orogen and the formation of the basin associated with the late Paleozoic Eastern Andean Metamorphic Complex.

Golfo San Jorge basin. According to the structural style, the Golfo San Jorge basin has been divided into five different regions. The North Flank, South Flank, and Basin Center are characterized by E-W normal faults where each region is dominated by dipping directions basinward (Figari et al., 1999; Sylwan et al., 2011). Westward, the San Bernardo fold belt and Western Flank are defined by positive tectonic inversion features, the former characterized by the domain of N-S contractional structures and the latter by NNW-SSE structures with a lower degree of 
inversion (Fitzgerald et al., 1990; Figari et al., 1999; Sylwan et al., 2011).

Figari et al. (1999) have pointed out that the tectonic evolution of this basin was conditioned, to a large degree, by Paleozoic lineaments, among which the oldest ones being recognized are transtensional structures associated with the Tepuel-Genoa basin (Ugarte, 1966; Forsythe, 1982). Several authors have highlighted two major tectonic episodes during the filling of the Golfo San Jorge basin and a posterior compressive phase (Fitzgerald et al., 1990; Peroni et al., 1995; Uliana et al., 1995; Chelotti, 1997; Figari et al., 1999; Sylwan et al., 2011, among others). The oldest event is an early rifting during the Jurassic and the posterior one during the Titho-Neocomian, characterized by NW-SE- oriented half-grabens, which conditioned depocenters development in the central and western sector (Miller and Marino, 2019). The other episode, associated with the Upper Chubutian depocenters, is controlled by WNW-ENE to W-E normal faults reaching its major development in the eastern sector and offshore the basin, though it can be observed crossing the central sector of the folded belt until the Río Mayo depocenter, in the west. This second tectonic event reactivated some Neocomian faults, encouraging their propagation with obliqueslip (Sylwan et al., 2011).

The compressive phase, which structured the central sector of the basin as a fold belt by the reactivation of former half-grabens, was generally assigned to the Neogene (Fitzgerald et al., 1990; Homovc et al., 1995), though it has been lately pointed out that the Andean compression started prior to the Late Cretaceous (Folguera and Ramos, 2011; Ramos, 2015) or during the late Lower Cretaceous (Aptian) (Gianni et al., 2015; Navarrete et al., 2018; Miller and Marino, 2019).

The upper Chubutian depocenters have been considered as part of an extensive foreland basin, in which the N-S extension of the eastern sector would be the result of a W-E compression in the frame of an unconfined basin. Associated with this tectono-stratigraphic scenario, Gianni et al. (2015) and Navarrete et al. (2018), consider Matasiete and Pozo D-129 formations as syn-inversion sequences, so this proposal includes basal Chubutian depocenters, while Ramos (2015) link the Castillo Formation to a foreland framework. According to Allard et al. (this issue), the tectonostratigraphic context during the deposition of the basal units of the Chubut Group (Barremian- Albian) was controlled by normal fault reactivations, while a reverse-reactivation scenario was the dominant regime during the record of the Laguna Palacios Formation (late Upper Cretaceous). The Chubut Group in the South Flank was associated with the "second rifting stage", characterized by propagation and linkage of W-E to WNW-ESE fault (Paredes et al., 2018). Previously, a compressive deformation has been registered to the west of the San Bernardo fold belt, which is located between the Liassic marine sedimentation and the Dogger andesitic volcanism (Allard, this issue; Navarrete et al., 2018).

The basin structure in the continental sector presents three large regions (Fig. 1A): the central one where the San Bernardo fold belt outcrops, with structural relief up to $1000 \mathrm{~m}$ a.s.l. The belt includes a general N-S structural trend and others orientation as NNW-SSE (e.g., Sierra Nevada Anticline), NNE-SSW (e.g., Perales Anticline) and WNWESE faults that show low-degree of inversion as in the Sur Río Deseado depocenter (Allard et al., this issue). Both the structures controlling these regions, as well as the main depocenters location, can be analyzed in the maps of Figari et al. (1999, 2015).

The eastern sector of the fold belt which includes the North and South flanks and Basin Center (Figari et al., 1999; Sylwan et al., 2011), possesses a marked transverse structure to the Atlantic margin, characterized by numerous W-E-oriented normal faults in the vicinity of the margin, that softly change to WNW-ESE towards the continent core, an orientation that becomes dominant (Fig. 1A). Detailed subsurface studies in the North and South flanks and Center Basin show a complexity resulting from the control role of basement faults. In the Manantiales Behr oilfield, Giampaoli (2015) recognized syn-sedimentary basement faults active during Neocomian rifting, and others that only deform the sedimentary cover. Because the Pozo D-129 Formation acted as a structural decoupling level, the reactivation of the pre-existent basement fabric had little influence on the development of faulting in the sedimentary cover. Moreover, in the Manantiales Behr, NW faults and their interrelations with W-E to WNW-ESE faults has been synthesized by Guerra et al. (2019) in two stages: 1) for the late Jurassic-Early Cretaceous, the basement faults are part of the limit of a complex horst associated with smaller curved faults connected to a hard-linked synthetic relay ramp, and 2) for the upper Cretaceous-Tertiary, this fault complex evolved to an echelon system with individual E-W strikes developed over NNW basement fault.

The Cerro Dragón oilfield in the North Flanks displays a NE-SW striking basement-involved normal faults that attain its maximum throw on top of the volcanic basement and was active during deposition of the Las Heras Group and Pozo D-129 Formation (Paredes et al., 2013). Pre-existing structural fabrics in the basement of the South Flank show NW-SE and NE-SW oriented faults. They control the location and geometry of wedge-shaped half grabens from the "main synrift phase" infilled with Middle Jurassic volcanic-volcaniclastic rocks and lacustrine units of Late Jurassic to Early Cretaceous age (Paredes et al., 2018).

Significant changes in the regional structural pattern between faults oriented transverse to the Atlantic margin and other parallel faults towards the continent core can be recognized to both sides of the $69^{\circ} \mathrm{W}$, in the Golfo San Jorge and the Deseado basins (Fig. 1A). This limit is also the Andean deformation front in the Patagonian foreland ("Miocene tectonic front" of Giacosa et al., 2010; "broken foreland eastern limit" of Bilmes et al., 2013, among others).

Cañadón Asfalto Basin. The Cañadón Asfalto basin has a considerable extension if its northernmost sector below the Somuncurá plateau is included (Cañadón Asfalto-Somuncurá basin, Cortiñas, 1996). The bestknown sector is located between the $42^{\circ}$ and $44^{\circ} 30^{\prime} \mathrm{S}$, where the Gastre, Gan Gan, Fossatti, General Racedo, Gorro Frigio, and Paso de Indios depocenters are found (Figari et al., 2015). The initial accumulations of early Jurassic age ( $\sim 188 \mathrm{Ma})$ are of particular interest to the present basin tectonic analysis, including rift-related volcano-sedimentary deposits accumulated in NNW-SSE to NW-SE- oriented halfgrabens of NE vergence, in the "lower Jurassic and Cretaceous depocenters" (Figari et al., 2015).

Several models were proposed in relation to the tectonic framework of the Cañadón Asfalto basin during the Jurassic inception, including a half-graben system generated by simple extension (Figari and Courtade, 1993), a pull-apart basin (Silva Nieto et al., 2002), differential subsidence of rotated and tilted blocks linked to transtensional strike-slip tectonic and to one or several thermal subsidence episodes (Ranalli et al., 2011), and a rift system associated with the Gondwana fragmentation (Figari et al., 2015).

Concerning basement structures control, it is possible to highlight several issues. Ranalli et al. (2011) stated that the depocenter limiting structures and the general orientation of the basin outcropping sectors were related to the orientations of the igneous-metamorphic basement structures. Moreover, these authors claimed that the relation between regional stress and the orientation of pre-existing structures determined the dominant regime in each sector (extension, transtension). On the other hand, and in association with the extension that generates the basin, Figari (2005) has pointed out that low-angle basement faults probably controlled this extension event. Fig. 1B allows observing, in a simplified way, the coincidence between the strike and the dip direction of normal faults in the main depocenters concerning the dominant orientations and vergence of the Gondwanic basement. What follows is an evaluation of evidence in critical sectors of some depocenters.

As previously described, the Taquetrén fault zone ("Taquetrén deformation front" of Echaurren et al., 2016; "Río Chubut Medio fault" of Bucher et al., 2019; "Río Chubut Medio-Taquetrén Thrust Fault" of Renda et al., 2019) presents abundant evidence of recurrent tectonic activity, including an early extensional phase followed by 
compressional re-shearing of the Paleozoic mylonitic fabric.

Gorro Frigio Depocenter. The Taquetrén range frontal structure, located between the Gorro Frigio and Gastre depocenters, shows evidence of an extensional and two main compressional re-shearing starting from the Paleozoic mylonitic fabric, so it can be used to test the faults recurrent behavior concerning the Paleozoic basement structures. The range structural relief of more than $1200 \mathrm{~m}$ a.s.l. is associated with a high-angle reverse fault of SW sense, with an $\mathrm{N} 30^{\circ} \mathrm{W}$ strike along more than $100 \mathrm{~km}$, changing in its extremes to N-S orientations. Figari and Courtade (1993) interpreted this fault as the edge of an extensional depocenter that was inverted during the Cenozoic.

At depth, the fault zone geometry has been interpreted as a main fault, together with two other synthetic reverse faults (Echaurren et al., 2016). Considering outcropping, the frontal sector of the fault zone is a rectilinear lineament with triangular facets, the product of the Quaternary reactivations (Costa et al., 1996). Behind the Quaternary deformation front, the main fault presents, in its upper block, a belt of upper-Paleozoic granitic mylonites whose planar fabric is parallel to the faults (Renda et al., 2017). The northern sector of the Taquetrén fault exhumes igneous and metamorphic rocks along with Paleozoic mylonites, sediments and volcanic rocks of the initial syn-rift phase. Towards the south, outcrop exposures are representing the late syn-rift phase and the post-rift stage (Echaurren et al., 2016). Between both stages starting from the Berriasian and the Hauterivian, a compressional phase reactivated the Taquetrén fault with a reverse sense (Echaurren et al., 2016). Later, a new Taquetrén range uplifting was associated with the deformation of upper Cretaceous-Paleocene sedimentary rocks together with Eocene volcanic rocks. This new compressional event allowed the deposition of Miocene continental sedimentary rocks (Ruiz, 2006; Bucher et al., 2019).

Paso de Indios Depocenter. Similarly to the Taquetrén fault, in the Pichiñanes range (Fig. 1A) the syn-extensional sequence of the Jurassic rift is controlled by an $\mathrm{N} 30^{\circ} \mathrm{W}$-striking normal fault dipping to the NE, currently located on the Chubut river, in the southern sector of the range which was inverted prior to the deposition of Los Adobes Formation (Allard et al., 2011; Allard, 2015). Concerning the Carboniferous basement located in the range core, the $\mathrm{S}_{2}$ dominant foliation in the high-grade metamorphic rocks strikes NW, defining a penetrative fabric parallel to the fault. The southernmost sector of the Paso de Indios depocenter between Los Altares and Paso de Indios, includes the Puesto Gilbert basalts and the Cañadón Asfalto Formation, as part of the Paso de Indios Group (Anselmi et al., 2000). This syn-rift sequences outcrops exhibit the same orientation as the metamorphic fabrics of the La Potranca Formation and the La Rueda mylonitic granites (Fig. 1B) (Giacosa et al., 2008).

Gastre Depocenter. The depocenter outcrops that flank the Gastre trough, in the ranges of the Cerro Bayo and the Cerro La Bandera, are controlled by $\mathrm{N} 55^{\circ}-60^{\circ} \mathrm{W}$-striking faults. These structures could be well compared to the Cushamen Gondwanic structure, characterized by a marked megascopic foliation with intercalated shear belts striking $\mathrm{N} 50^{\circ}-55^{\circ} \mathrm{W}$ (Fig. 1B) (Giacosa et al., 2017); at depth, these structures have a strong magnetic fabric (Álvarez et al., 2014).

Part of the pre-rift basement is composed of late Triassic plutonic rocks from the Central Patagonia Batholith, which set following the nearby Paleozoic basement structures, represented by metamorphic foliations from the Calcatapul Formation and mylonitic fabrics from the Yancamil granite. The magnetic and magmatic foliations, and lineations that form the inner structure of the intrusive suggest that the different magma pulses rose and intruded as elongated tabular bodies striking NW-SE (Zaffarana et al., 2017).

\section{Synthesis}

In the preceding paragraphs, there is an attempt to update and clarify the structural relations that exist between basin structures and their basement structures, considering the data of some Mesozoic basins from the extra-Andean Patagonia, of which the Golfo San Jorge basin, main subject of the present volume, is pointed out as the most important one in economic terms. A clear understanding of the basementbasin relations is not feasible due to the lack of detailed petrologic and structural studies together with reduced outcrop exposures, and the absence of high-resolution seismic sections at basement levels. Besides, in the subsurface realm, it is still necessary to calibrate the lithostratigraphic boundaries based on cutting control and to refine seismicstratigraphic interpretations.

In order to evaluate basement-basin links, two parameters have been taken into account: a) orthogonal or oblique orientation of shear zones and foliation zones, concerning Jurassic extensional stress orientation, and b) the relation between the dip-direction of basement structures and the depocenter-bounding faults.

The relationship between basement-faults orientation and regional extensional paleostress during the Jurassic determines coaxial or noncoaxial reactivation scenarios. The reconstructions of absolute plate motion during the Jurassic (Müller et al., 2016) show two extensional orientations: a) $\mathrm{N}^{\circ} 0^{\circ}-270^{\circ}$ during Early Jurassic (200 Ma) and Middle to Late Jurassic boundary ( $160 \mathrm{Ma}$ ), and b) $\mathrm{N}^{\circ} 0^{\circ}-210^{\circ}$ during Early to Middle Jurassic boundary (180 Ma) and the Tithoneocomian (140 Ma).

As a synthesis, it can be stated that an N-S line along the $69^{\circ} \mathrm{W}$ between the North Patagonian and the Deseado regions (Fig. 1B), which expresses either the occurrence or absence of structural relief to both sides of it, approximately indicates the extent of the Andean deformation in the Patagonian foreland. To both sides of this orogenic front, relevant differences are observed in the basement structures participation in the configuration of the basins.

Eastwards of the $69^{\circ} \mathrm{W}$, the Mesozoic basins sectors located closer to the Atlantic margin and on the continental shelf are controlled by W-Eoriented faults, orthogonal to the continental margin. Although this orientation has no relation with the already known basement structures, some isolated cases of secondary grabens to the main rift show some basement influence, as the "NW-graben" of the San Julián basin. In these eastern areas, the Neopaleozoic basin of La Golondrina in the Deseado region presents an NNW configuration suggesting a basement control. These observations suggest that during the Gondwana rifting and the subsequent continental drift, the structural geometry of the Mesozoic basins in the sectors adjacent to the Atlantic margin presents scarce evidence to infer the influence of the Paleozoic basement structures in their inception and evolution. However, current studies suggest some exceptions in sectors close to intra-basin basement highs with thin thicknesses of overlying sedimentary successions, when NW basement faults have a complex interplay with later W-E to WNW-ESE faults.

Towards the continent interior, basement control evidence occurs regarding the basin inception and initial basin development. The most reliable evidence can be found in several depocenters of the Cañadón Asfalto basin, starting from the same limit separating this basin from the Golfo San Jorge basin, and also in the distribution of the units that form the Jurassic rift tecto-sequences and its relation to the structures and fabrics of the pre-rift basement. The pre-rift basement and the rift sequence outcrops as structural relief of different heights (500 - > $1000 \mathrm{~m}$ a.s.l.), generally associated with reverse faults with tectonic inversion of their main normal faults. The pre-rift basement is composed of Paleozoic igneous-metamorphic rocks characterized by a) ductile and ductile-brittle shear zones and, b) thin shear zones interlayered with axial-plane and crenulation foliation zones. With conveniently-oriented structures concerning the extensional stress, they might have determined the initial location of rifts.

Direct evidence relating basement-basin structures in the Golfo San Jorge basin is currently insufficient, so interpretations bear a high level of uncertainty. On the Ferrarotti farm, to the west of the San Bernardo fold belt, the Neopaleozoic sedimentary rocks of the NNW-SSE-striking Tepuel-Genoa transtensional basin, and the coincidence in the fold belt structural trend might be indicative of certain control considering the 
lower Chubutian depocenters orientation in that part of the basin (Figari et al., 2015). Immediately to the north of the Golfo San Jorge basin, those rift sectors with tectonic inversion show a consistent similarity relationship with the Paleozoic orogenic fabrics. This similarity can be seen in the orientation and dip-direction of normal faults and basement structures, either being shear zones or axial-plane foliation zones. As observed in the Taquetrén range, these sectors present a recurrent deformation starting from the initial normal re-shearing, continuing with several tectonic inversion phases, and finishing with compressional Quaternary deformations.

As the Gondwanic orogenic fabric presents a regionally curved path, the basins morphology, whose geometry was inherited from the basement, also reproduce such variation. In an overall manner, the orientations that reflect this curvature strike to the $\mathrm{N} 30^{\circ} \mathrm{W}$ between $44^{\circ} 15^{\prime} \mathrm{S}$ and $42^{\circ} 40^{\prime} \mathrm{S}, \mathrm{N} 60^{\circ} \mathrm{W}$ between $42^{\circ} 40^{\prime} \mathrm{S}$ and $41^{\circ} 00^{\prime} \mathrm{S}$, and W-E between $41^{\circ} 00^{\prime} \mathrm{S}$ and $39^{\circ} 00^{\prime} \mathrm{S}$ (Fig. 1B). In terms of geodynamics, this regional design of the orogenic fabric coincides with the Gondwanic magmatic arcs location, the Late Devonian-Carboniferous western arc that is NNW-oriented, which crosses a significant part of Patagonia, and a lower Permian arc in northern Patagonia (Ramos, 2008).

\section{Declaration of competing interest}

- No conflict of interests regarding this publication.

- This manuscript has not been submitted to, nor is under review at, another journal or other publishing venue.

- The authors have no affiliation with any organization with a direct or indirect financial interest in the subject matter discussed in the manuscript.

\section{Acknowledgments}

I would like to offer my special thanks to Dr. J. Paredes for inviting me to participate in this special issue on the Geology of the Golfo San Jorge Basin. I am also particularly grateful to Drs. J. Allard, N. Foix and P. González for their discussions on the basement- basin relations in Patagonia. Finally, I would like to thank Romina Sulla for helping me with the manuscript preparation and posterior translation.

\section{Appendix A. Supplementary data}

Supplementary data to this article can be found online at https:// doi.org/10.1016/j.jsames.2019.102407.

\section{References}

Allard, J., 2015. Arquitectura, estilos fluviales y controles externos sobre la sedimentación continental del Cretácico en la cuenca de Cañadón Asfalto, Chubut. Ph.D. Thesis. Universidad Nacional de la Patagonia San Juan Bosco, Facultad de Ciencias Naturales, Argentina, pp. 526.

Allard, J., Giacosa, R., Paredes, J., 2011. Relaciones estratigráficas entre la Formación Los Adobes (Cretácico inferior) y su sustrato Jurásico: implicancias en la evolución tectónica de la cuenca de Cañadón Asfalto, Chubut, Argentina. In: $18^{\circ}$ Congreso Geológico Argentino, Actas CD, pp. 998-999 (Neuquén).

Allard, J., Foix, N., Bueti, S., Sánchez, F., Ferreira, L., Atencio, M, this issue. Comparative structural analysis of inverted structures in the San Bernardo fold belt (Golfo San Jorge basin, Argentina): inversion controls and tecto-sedimentary context of the Chubut Group. J. South Am. Sci., (this issue).

Álvarez, D., Peroni, J., Giacosa, R., Silva Nieto, D., Busteros, A., Lagorio, S., 2014. Evidencias magnetométricas de las estructuras andinas y pre-andinas en las regiones de Gastre y Cushamen ( $41^{\circ} 30^{\prime}-43^{\circ} 00^{\prime} \mathrm{S}$, SO del Macizo Norpatagónico). In: $19^{\circ}$ Congreso Geológico Argentino, S2, vols. 2-3. pp. 1550-1551 (Actas CD, Córdoba).

Anselmi, G., Panza, J., Cortés, J., Ragona, D., Genini, A., 2000. Hoja Geológica 4569-II, El Sombrero, Provincia del Chubut. Serv. Geol. Miner. Argent. Bol. 271, 92 (Buenos Aires).

Bilmes, A., D'Elia, L., Franzese, J., Veiga, G., Hernández, M., 2013. Miocene block uplift and basin formation in the Patagonian foreland: the Gastre Basin, Argentina. Tectonophysics 601, 98-111.

Buchanan, J., Buchanan, P., 1995. In: In: Buchanan, J., Buchanan, P. (Eds.), Basin Inversion 88. Geological Society Special Publication, London, pp. 596.

Bucher, J., García, M., López, M., Milanese, F., Bilmes, A., D'Elia, L., Naipauer, M., Sato,
A.M., Rapalini, A., Franzese, J., 2019. Tectonostratigraphic evolution and timing deformation in the Miocene Paso del Sapo Basin: implications for the Patagonian broken foreland. J. South Am. Earth Sci. 94. https://doi.org/10.1016/j.jsames.2019. 102212 .

Chelotti, L., 1997. Evolución tectónica de la Cuenca del Golfo San Jorge en el Cretácico y Terciario; algunas observaciones desde la interpretación sísmica. Bol. Inf. Pet. 49, $62-82$.

Clemson, J., Cartwright, J., Booth, J., 1997. Structural segmentation and the influence of basement structure on the Namibian passive margin. J. Geol. Soc. 154, 477-482.

Cortiñas, J.S., 1996. La Cuenca de Somuncurá - Cañadón Asfalto: sus límites, ciclos evolutivos del relleno sedimentario y posibilidades exploratorias. In: XIII Congreso Geológico Argentino y III Congreso de Exploración de Hidrocarburos 1. Actas, pp. 147-163 (Buenos Aires).

Cortiñas, J., Homovc, J., Lucero, M., Gobbo, E., Laffitte, G., Viera, A., 2005. Las cuencas de la región del Deseado. In: Chebli, G. (Ed.), Frontera exploratoria de la Argentina, 14. Instituto Argentino del Petróleo y Gas, pp. 289-306 (Buenos Aires).

Costa, C.H., Lizuaín, A.J., Cortés, J.M., Gardini, C.E., 1996. El frente de levantamiento andino de la sierra de Taquetrén, Provincia de Chubut. XIII Congreso Geológico Argentino y III Congreso de Exploración de Hidrocarburos. Actas 2, 397.

Coward, M., 1994. Inversion tectonics. In: In: Hancock, P. (Ed.), Continental Deformation, vol. 2. Pergamon Press, pp. 289-304.

Cucchi, R., Busteros, A., Lema, H., Dalponte, M., Espejo, P., 2001. Hoja Geológica 4169-II, Los Menucos, Provincia de Río Negro. Serv. Geol. Min. Arg. Bol. 265, 105 (Buenos Aires).

Daly, M., Chorowicz, J., Fairhead, J., 1989. Rift basin evolution in Africa: the influence of reactivated steep basement shear zones. Geol. Soc. London. Spec. Publ. 44, 309-334.

Di Persia, C., 1962. Acerca del descubrimiento del Precámbrico en la Patagonia Extrandina (provincia de Santa Cruz). Primeras Jornadas Geológicas Argentinas (San Juan). Actas 2, 65-68 (Buenos Aires).

Echaurren, A., Folguera, A., Gianni, G., Orts, D., Tasara, A., Encinas, A., Giménez, M., Valencia, V., 2016. Tectonic evolution of the North Patagonian Andes ( $41^{\circ}-44^{\circ} \mathrm{S}$ ) through recognition of syntectonic strata. Tectonophysics 677, 99-114.

Echaurren, A., Oliveros, V., Folguera, A., Ibarra, F., Creixell, C., Lucassen, F., 2017. Early Andean tectonomagmatic stages in north Patagonia: insights from field and geochemical data. J. Geol. Soc. Lond. 174, 405-421. https://doi.org/10.1144/jgs2016087.

Faccenna, C., Nalpas, T., Brun, J.P., Davy, P., Bosi, V., 1995. The influence of pre-existing thrust faults on normal fault geometry in nature and in experiments. J. Struct. Geol. 17, 1139-1149.

Figari, E., 2005. Evolución tectónica de la cuenca de Cañadón Asfalto (zona del Valle Medio del Rio Chubut. Ph.D. Thesis. Universidad Nacional de Buenos Aires, Facultad de Ciencias Exactas y Naturales, pp. 198.

Figari, E.G., Courtade, S.F., 1993. Evolución tectosedimentaria de la Cuenca de Cañadón Asfalto, Chubut, Argentina. In: XII Congreso Geológico Argentino y II Congreso de Exploración de Hidrocarburos Actas I: 66-77, Mendoza.

Figari, E., Strelkov, E., Laffitte, G., Cid de la Paz, M., Courtade, S., Celaya, J., Vottero, A., Lafourcade, S., Martínez, R., Villar, H., 1999. Los sistemas petroleros de la Cuenca del Golfo San Jorge: Síntesis estructural, estratigráfica y geoquímica. In: $4^{\circ}$ Congreso de Exploración y Desarrollo de Hidrocarburos. Actas, Buenos Aires, pp. 197-237.

Figari, E.G., Scasso, R.A., Cúneo, R.N., Escapa, I., 2015. Estratigrafía y evolución geológica de la Cuenca de Cañadón Asfalto, provincia del Chubut, Argentina. Lat. Am. J. Sedimentol. Basin Anal. 22 (2), 135-169.

Figueiredo, A., Pellón de Miranda, A., Ferreira, R., Zalán, P., 1996. Cuenca de San Julián. In: In: Ramos, V., Turic, M. (Eds.), Geología y Recursos Naturales de la Plataforma Continental Argentina 11. Asociación Geológica Argentina e InstitutoArgentino del Petróleo, Buenos Aires, pp. 193-212.

Fitzgerald, M., Mitchum, M., Uliana, M., Biddle, K., 1990. Evolution of the San Jorge basin. Argentina. Am. Assoc. Pet. Geol. Bull. 74, 879-920.

Folguera, A., Ramos, V.A., 2011. Repeated eastward shifts of arc magmatism in the Southern Andes: a revision to the long-term pattern of Andean uplift and magmatism. J. South Am. Earth Sci. 32 (4), 531-546.

Folguera, A., Fernández Paz, L., Iannelli, S., Navarrete, C., Echaurren, A., Gianni, G., Butler, K., Horton, B., Litvak, V., Encinas, A., Orts, D., this issue. The origin of the san Jorge gulf basin as a syn-contractional extensional basin in the context of the meso to Cenozoic Patagonian evolution. J. South Am. Sci., (this issue).

Forsythe, R., 1982. The Late Paleozoic to Early Mesozoic evolution of southern South America: a plate tectonic interpretation: J. Geol. Soc. (Lond.) 139, 671-682.

Fracchia, D., Giacosa, R., 2006. Evolución estructural del basamento ígneo-metamórfico en la estancia Las Tres Hermanas, noreste de la Comarca del Deseado, Santa Cruz. Rev. Asoc. Geol. Argent. 61 (1), 118-131.

Franzese, J., Spalletti, L., Gómez Perez, I., Macdonald, D., 2003. Tectonic and paleoenvironmental evolution of Mesozoic sedimentary basins along the Andean foothills of Argentina $\left(32^{\circ}-54^{\circ} \mathrm{S}\right)$. J. South Am. Sci. 16, 81-90.

García-Sansegundo, J., Cuesta, A., Farías, P., Gallastegui, G., Heredia, N., Giacosa, R., 2008. La estructura de la región de Río Chico (Macizo Nordpatagónico, Argentina). In: $17^{\circ}$ Congreso Geológico Argentino, Actas, pp. 19-20 (S.S. Jujuy).

Gawthorpe, R., Leeder, M., 2000. Tectono-sedimentary evolution of active extensional basins. Basin Res. 12, 195-218.

Giacosa, R., 2001. Zonas de cizalla Neopaleozoicas en el sector oriental del Macizo Nordpatagonico. Rev. Asoc. Geol. Argent. 56 (2), 131-140.

Giacosa, R., Heredia, N., 2004. Structure of the Northpatagonian Andes thick-skinned fold and thrust belt, southern central Andes, Argentina ( $41^{\circ}-42^{\circ}$ S). J. South Am. Earth Sci. 18 (1), 61-72.

Giacosa, R., Márquez, M., Nillni, A., Fernández, M., Parisi, C., Afonso, J., Paredes, J., Sciutto, J., 2004. Litología y estructura del basamento ígneo-metamórfico del borde SO del Macizo Nordpatagónico al oeste del río Chico ,(Cushamen, Chubut, $42^{\circ} 10^{\prime} \mathrm{S}$ - 
$70^{\circ} 30^{\prime}$ O). Rev. Asoc. Geol. Argent. 59 (4), 569-577.

Giacosa, R., López, R., Guido, D., 2006. Evidencias de una zona de cizalla dúctil en el basamento pre-Pérmico de la región del Deseado (Bahía Laura, Santa Cruz). In: In: Hong, F. (Ed.), XII Reunión sobre Microtectónica y Geología Estructural. Asociación Geológica Argentina, Serie D: Publicación Especial Nº, vol. 6. pp. 180-185 (Buenos Aires).

Giacosa, R., Márquez, M., Fernández, M.I., 2008. Estructura e interpretación tectónica del granito milonítico La Rueda: región central del Chubut. In: $17^{\circ}$ Congreso Geológico Argentino. Actas, pp. 835-836 (S.S. Jujuy).

Giacosa, R., Zubia, M., Sánchez, M., Allard, J., 2010. Meso-Cenozoic tectonics of the southern Patagonian foreland: structural evolution in the eastern Deseado Region and implications for Au-Ag Jurassic deposits (Santa Cruz, Argentina). J. South Am. Earth Sci. 30 (3-4), 134-150.

Giacosa, R., Silva Nieto, D., Busteros, A., Lagorio, S., Hernando, I., 2017. Estructuras preandinas y andinas en la región Occidental del Macizo Nordpatagónico ( $\left.41^{\circ}-43^{\circ} \mathrm{S}\right)$. $20^{\circ}$ Congreso Geológico Argentino. Actas ST 13, 60-65 (S.M. Tucumán).

Giampaoli, P., 2015. Caracterización de sistemas de fallas extensionales utilizando perfiles y mapas de desplazamiento: ejemplos del Cretácico de la cuenca del Golfo San Jorge. Rev. Asoc. Geol. Argent. 72, 107-119.

Gianni, G., Navarrete, C., Orts, D., Tobal, J., Folguera, A., Giménez, M., 2015. Patagonian broken foreland and related synorogenic rifting: the origin of the Chubut Group Basin. Tectonophysics 649, 81-99.

Gontijo-Pascutti, A., Bezerra, F., Terra, E., Almeida, J., 2010. Brittle reactivation of mylonitic fabric and the origin of the Cenozoic Rio Santana Graben, southeastern Brazil. J. South Am. Earth Sci. 29, 522-536.

González, P., Sato, A.M., Naipauer, M., Varela, R., Basei, M., Sato, K., Llambías, E., Chemale, F., Castro Dorado, A., 2018. Patagonia-Antarctica Early Paleozoic conjugate margins: Cambrian synsedimentary silicic magmatism, U-Pb dating of K-bentonites, and related volcanogenic rocks. Gondwana Res. 63, 186-225.

Greco, G., González, P., González, S., Sato, A.M., Basei, M., Tassinari, C., Sato, K., Varela, R., Llambías, E., 2015. Geology, structure and age of the Nahuel Niyeu formation in the Aguada Cecilio area, North Patagonian Massif, Argentina. J. South Am. Earth Sci. $65,12-32$.

Guerra, G., Giampaoli, P., López, R., Marinho, G., Allard, J., 2019. Influence of Basement Fault Geometry and Orientation in Extensional Architecture: A Study Case at Manantiales Behr Oilfield at North Flank, Golfo San Jorge Basin. AAPG Ice 2019, Abstract.

Gupta, S., Cowie, P., Dawers, N., Underhill, J., 1998. A mechanism to explain rift-basin subsidence and stratigraphic patterns through fault-array evolution. Geology 26, 595-598.

Henza, A., Withjack, M., Schlische, R., 2011. How do the properties of a pre-existing normal-fault population influence fault development during a subsequent phase of extension? J. Struct. Geol. 33, 1312-1324.

Homovc, J., Constantini, L., 2001. Hydrocarbon exploration potential within intra-plate shear related depocenters: Deseado and San Julián basins, southern Argentina. Am. Assoc. Pet. Geol. Bull. 85 (10), 1795-1816.

Homovc, J., Constantini, L., de Miranda, A., Ferreira, R., 1996. Evolution of the Deseado Massif and its relationships with the san Julián offshore area, Argentina (abs. In: AAPG Annual Convention, Program with Abstracts, pp. 66. v.5.

Homovc, J.F., Conforto, G.A., Lafourcade, P.A., Chelotti, L.A., 1995. Fold belt in the San Jorge Basin, Argentine: an example of tectonic inversion. In: In: Buchanan, J.G., Buchanan, P.G. (Eds.), Basin Inversion. Special Publication, vol. 88. Geological Society of London, pp. 235-248.

Japas, S., Vizan, H., Prezzi, C., Geuna, S., Franzese, J., Renda, E., Oriolo, S., 2017. Pangea, autosubducción y cuencas extensionales mesozoicas del margen sudoeste de Gondwana. $20^{\circ}$ Congreso Geológico Argentino. Actas ST 13, 76-82 (S.M. Tucumán).

Kristensen, T.B., Rotevatn, A., Peacock, D., Henstra, G.A., Midtkandal, I., Grundvåg, S. 2016. Structure and flow properties of syn-rift border faults: the interplay between fault damage and fault-related chemical alteration (Dombjerg Fault, Wollaston Forland, NE Greenland). J. Struct. Geol. 92, 99-115.

Márquez, M., Giacosa, R., 2000. Deformaciones dúctiles paleozoicas y corrimientos terciarios en el Neopaleozoico del Chubut. Rev. Asoc. Geol. Argent. 55 (4), 398-402.

Martino, R., Guareschi, A., Carignano, C., 2012. Influencia de la tectónica preandina sobre la tectónica andina: el caso de la falla de Sierra Chica, Sierras Pampeanas de Córdoba. Rev. Asoc. Geol. Argent. 69 (2), 163-178.

Maurin, J.-C., Guiraud, R., 1993. Basement control in the development of the early Cretaceous west and central African rift system. Tectonophysics 228, 81-95.

Miller, M., Marino, J., 2019. New insights from the Neocomian basins in the west of Chubut and Santa Cruz provinces, Argentina. J. South Am. Earth Sci. https://doi.org/ 10.1016/j.jsames.2019.102255.

Mizerit, I., Suárez, R., Voglino, S., Aranda, D., Giacosa, R., González, P., 2014. Fallas transcurrentes en estadios tardíos de la milonitización en los granitoides triásicos del borde septentrional del Macizo Nordpatagónico (Río Negro). In: $19^{\circ}$ Congreso Geológico Argentino, S2, vols. 2-40. pp. 1624-1625 (Actas CD, Córdoba).

Moreira, P., González, P., Fernández, R., Echeveste, H., Schalamuk, I., Etcheverry, R., 2012. El basamento de bajo grado de las Estancias La Modesta y La Josefina, Macizo del Deseado, Provincia de Santa Cruz. Rev. Asoc. Geol. Argent. 60 (1), 49-63.

Morley, C.K., Haranya, C., Phoosongsee, W., Pongwapee, S., Kornsawan, A., Wonganan, N., 2004. Activation of rift oblique and rift parallel pre-existing fabrics during extension and their effect on deformation style: examples from the rifts of Thailand. J. Struct. Geol. 26, 1803-1829.

Morley, C., 2017. The impact of multiple extension events, stress rotation and inherited fabrics on normal fault geometries and evolution in the Cenozoic rift basins of Thailand. In: In: Childs, C. (Ed.), The Geometry and Growth of Normal Faults 439. Geological Society, London, pp. 413-445.

Mosquera, A., Ramos, V.A., 2006. Intraplate deformation in the Neuquén embayment. In:
In: Kay, S.M., Ramos, V.A. (Eds.), Evolution of an Andean Margin: A Tectonic and Magmatic View from the Andes to the Neuquén Basin (35 ${ }^{\circ}-39^{\circ}$ lat), vol. 407. Geological Society of America Special Paper, pp. 97-124.

Müller, R.D., Seton, M., Zahirovic, S., Williams, S.E., Matthews, K.J., Wright, N.M., Shephard, G.E., Maloney, K.T., Barnett-Moore, N., Hosseinpour, M., Bower, D.J. Cannon, J., 2016. Ocean basin evolution and global-scale plate reorganization events since Pangea breakup. Annu. Rev. Earth Planet Sci. 44, 38-107.

Navarrete, C.R., Gianni, G., Echaurren, A., Folguera, A., 2018. Lower Jurassic to early Paleogene Intraplate contraction in central Patagonia. In: In: Folguera, A., Contreras Reyes, E., Heredia, N., Encinas, A., Oliveros, V., Dávila, F., Collo, G., Giambiagi, L., Naipauer, M., Maksymowicz, A., Alvarez, O. (Eds.), The Evolution of the ChileanArgentinean Andes 10. Springer Earth System Sciences, pp. 245-271.

Navarrete, C., Gianni, G., Christiansen, R., Kamerbeek, Y., Periale, S., Folguera, A., 2019 Jurassic intraplate contraction of southern Patagonia: the El Tranquilo anticline area, Deseado Massif. J. South Am. Earth Sci. 94. https://doi.org/10.1016/j.jsames.2019. 102224.

Oviedo, N.V., Astini, R.A., 2014. Cubierta sedimentaria mesozoica. In: Martino, R.D., Guereschi, A.B. (Eds.), Geología y Recursos Naturales de la Provincia de Córdoba Relatorio del $19^{\circ}$ Congreso Geológico Argentino, pp. 435-471 (Córdoba).

Pankhurst, R.J., Rapela, C.W., Fanning, C.M., Márquez, M., 2006. Gondwanide continental collision and the origin of Patagonia. Earth Sci. Rev. 76, 235-257.

Paredes, J.M., Plazibat, S., Crovetto, C., Stein, J., Cayo, E., Schiuma, A., 2013. Fault kinematics and depocenter evolution of oil-bearing, continental successions of the Mina del Carmen Formation (Albian) in the Golfo San Jorge basin, Argentina. J. South Am. Earth Sci. 46, 63-79.

Paredes, J.M., Aguilar, M., Ansa, A., Giordano, S., Ledesma, M., Tejeda, S., 2018. Inherited discontinuities and fault kinematics of a multiphase, non-colinear extensional setting: subsurface observations from the South Flank of the Golfo San Jorge basin, Patagonia. J. South Am. Earth Sci. 81, 87-107.

Paton, D., Underhill, J., 2004. Role of crustal anisotropy in modifying the structural and sedimentological evolution of extensional basins: the Gamtoos Basin, South Africa. Basin Res. 16, 339-359.

Permuy Vidal, C., Moreira, P., Guido, D., Fanning, C., 2014. Linkages between the southern Patagonia Pre-Permian basements: new insights from detrital zircons U-Pb SHRIMP ages from the Cerro Negro District. Geol. Acta 12 (2), 137-150.

Peroni, G., Hedegus, A., Cerdan, J., Legarreta, L., Uliana, M., Laffitte, G., 1995. Hydrocarbon accumulation in an invertid segment of the Andean foreland: San Bernardo belt, central Patagonia. In: Tankard, A., Suárez, S., Welsink, H. (Eds.), Petroleoum Basins of South America. Memoir 62. American Association of Petroleoum Geologists, pp. 403-419.

Phillips, T., Jackson, C., Bell, R., Duffy, O., Fossen, H., 2016. Reactivation of intrabasement structures during rifting: a case study from offshore southern Norway. J. Struct. Geol. 91, 54-73.

Ramos, V.A., 2008. Patagonia: a Paleozoic continent adrift ? J. South Am. Earth Sci. 26, 235-251.

Ramos, V.A., 2015. Evolución de la cuenca Golfo San Jorge: su estructuración y régimen tectónico. Rev. Asoc. Geol. Argent. 72 (1), 16-24.

Ramos, V.A., Kay, S., 1990. Triassic rifting and associated basalts in the Cuyo basin, central Argentina. In: In: Harmon, R.S., Rapela, C.W. (Eds.), The Andean Magmatism and its Tectonic Setting, vol. 265. Geological Society of America Special Paper, pp. 79-92.

Ranalli, J., Peroni, G., Boggetti, D., Manoni, R., 2011. In: Cuenca Cañadón Asfalto, modelo tectosedimentario. Simposio Cuencas Argentinas: visión actual, VIII Congreso de Exploración y Desarrollo de Hidrocarburos. Instituto Argentino del Petróleo y Gas, Buenos Aires, pp. 185-215.

Reeve, M., Bell, R., Jackson, A., 2014. Origin and significance of intra- basement seismic reflections offshore western Norway. J. Geol. Soc. 171, 1-4.

Renda, E., Oriolo, S., Vizan, H., 2017. Comparación estructural entre dos unidades de la Formación Mamil Choique: granitoide de Sierra del Medio ( $\sim 253 \mathrm{ma})$ y granodiorita Paso del Sapo ( $\sim 314 \mathrm{ma}) .20^{\circ}$ Congreso Geológico Argentino. Actas ST13 141-145 (S.M. Tucumán).

Renda, E., Álvarez, D., Prezzi, C., Oriolo, S., Vizán, H., 2019. Inherited Basement Structures and Their Influence in Foreland Evolution: A Case Study in Central Patagonia. Tectonophysics, Argentina. https://doi.org/10.1016/j.tecto.2019. 228232.

Ring, U., 1994. The influence of preexisting structure on the evolution of the Cenozoic Malawi rift (East African rift system). Tectonics 13, 313-326.

Roberts, A., 2018. Análisis sismoestratigráfico y estructural del bloque Estación Fernández Oro, cuenca Neuquina, provincia de Río Negro. Tesis final de Licenciatura. Universidad Nacional de Río Negro, General Roca, pp. 79.

Ruiz, L., 2006. Estudio Sedimetológico y Estratigráfico de las Formaciones Paso del Sapo y Lefipán en el Valle Medio del Río Chubut Trabajo final de Licenciatura. Universidad Nacional de Buenos Aires, Buenos Aires, pp. 98.

Salomon, E., Koehn, D., Passchier, C., 2015. Brittle reactivation of ductile shear zones in NW Namibia in relation to South Atlantic rifting. Tectonics 34, 70-85.

Silvestro, J., Zubiri, M., 2008. Convergencia oblicua: modelo estructural alternativo para la Dorsal neuquina. Rev. Asoc. Geol. Argent. 63 (1), 49-64.

Silva Nieto, D., Cabaleri, N., Salani, F., Coluccia, A., 2002. Cañadón Asfalto, una cuenca de tipo "“pull-apart" en el área de Cerro Cóndor, Provincia del Chubut. In: XV Congreso Geológico Argentino Actas: 238-243, Calafate. AGA.

Sylwan, C., Droeven, C., Iñigo, J., Mussel, F., Padva, D., 2011. Cuenca del Golfo San Jorge. In: 8vo Congreso de Exploración y Desarrollo de Hidrocarburos, Simposio Cuencas Argentinas, visión actual. Instituto Argentino del Petróleo y Gas, Buenos Aires, pp. 139-183.

Ugarte, F., 1966. La cuenca compuesta Carbonífero-Jurásica de la Patagonia meridional Anales Universidad Nacional de la Patagonia San Juan Bosco, 2. Cienc. Geol. 1, 37-68 
(Comodoro Rivadavia).

Uliana, M.A., Arteaga, M.E., Legarreta, L., Cerdán, J.J., Peroni, G.O., 1995. Inversion structures and hydrocarbon occurrence in Argentina. In: In: Buchanan, J.G., Buchanan, P.G. (Eds.), Basin Inversion 88. Geological Society Special Publication, pp. 211-233.

Viera, R., Pezzuchi, H., 1976. Presencia de sedimentitas pérmicas en contacto con rocas del Complejo metamórficö de la Patagonia extrandina, estancia Dos Hermanos, provincia de Santa Cruz. Rev. Asoc. Geol. Argent. 31, 281-283.

Vizán, H., Prezzi, C.B., Geuna, S.E., Japas, M.S., Renda, E.M., Franzese, J., Van Zele, M.A., 2017. Paleotethys slab pull, self-lubricated weak lithospheric zones, poloidal and toroidal plate motions, and Gondwana tectonics. Geosphere 13 (5), 1-14.

Von Gosen, W., 2009. Stages of Late Palaeozoic deformation and intrusive activity in thewestern part of the North Patagonian Massif (southern Argentina) and their geotectonic implications. Geol. Mag. 146 (1), 48-71.

Whipp, P., Jackson, C., Gawthorpe, R., Dreyer, T., Quinn, D., 2014. Normal fault array evolution above a reactivated rift fabric; a subsurface example from the northern Horda Platform, Norwegian North Sea. Basin Res. 26 (4), 523-549.

Withjack, M., Schlische, R., Olsen, P., 2002. Rift-basin structure and its influence on sedimentary systems. Sedimentation in Continental Rifts. SEPM (Soc. Sediment. Geol.) Spec. Publ. 73, 57-81.

Zaffarana, C., Somoza, R., Orts, D., Boltshauser, B., Ruiz González, V., Puigdomenech, C., 2017. Estructura interna del Batolito de la Patagonia Central, Triásico tardío del Macizo Nordpatagónico. 20 Congreso Geológico Argentino. Actas ST13 169-174 (S.M. Tucumán). 